Article

\title{
The Response to Oxidative Stress in Listeria monocytogenes Is Temperature Dependent
}

\author{
Beatriz Manso ${ }^{1}$, Beatriz Melero ${ }^{1, *}\left(\mathbb{D}\right.$, Beatrix Stessl ${ }^{2,3}$, , Isabel Jaime ${ }^{1}$, Martin Wagner ${ }^{2,3}$, \\ Jordi Rovira ${ }^{1}$ and David Rodríguez-Lázaro ${ }^{1, *(1)}$ \\ 1 Department of Biotechnology and Food Science, Faculty of Sciences, University of Burgos, 09001 Burgos, \\ Spain; beatrizmg@ubu.es (B.M.); ijaime@ubu.es (I.J.); jorvira@ubu.es (J.R.) \\ 2 Institute of Milk Hygiene, Milk Technology and Food Science, Department for Farm Animals and Veterinary \\ Public Health, University of Veterinary Medicine, A-1210 Vienna, Austria; \\ Beatrix.Stess1@vetmeduni.ac.at (B.S.); Martin.Wagner@vetmeduni.ac.at (M.W.) \\ 3 Christian Doppler Laboratory for Molecular Food Analytics, University of Veterinary Medicine, \\ A-1210 Vienna, Austria \\ * Correspondence: bmelero@ubu.es (B.M.); drlazaro@ubu.es (D.R.-L.); \\ Tel.: +34-947-259-074 (B.M.); +34-947-259-323 (D.R.-L.)
}

Received: 14 February 2020; Accepted: 3 April 2020; Published: 5 April 2020

\begin{abstract}
The stress response of 11 strains of Listeria monocytogenes to oxidative stress was studied. The strains included ST1, ST5, ST7, ST6, ST9, ST87, ST199 and ST321 and were isolated from diverse food processing environments (a meat factory, a dairy plant and a seafood company) and sample types (floor, wall, drain, boxes, food products and water machine). Isolates were exposed to two oxidizing agents: $13.8 \mathrm{mM}$ cumene hydroperoxide (CHP) and $100 \mathrm{mM}$ hydrogen peroxide $\left(\mathrm{H}_{2} \mathrm{O}_{2}\right)$ at $10^{\circ} \mathrm{C}$ and $37^{\circ} \mathrm{C}$. Temperature affected the oxidative stress response as cells treated at $10{ }^{\circ} \mathrm{C}$ survived better than those treated at $37^{\circ} \mathrm{C} . \mathrm{H}_{2} \mathrm{O}_{2}$ at $37^{\circ} \mathrm{C}$ was the condition tested resulting in poorest L. monocytogenes survival. Strains belonging to STs of Lineage I (ST5, ST6, ST87, ST1) were more resistant to oxidative stress than those of Lineage II (ST7, ST9, ST199 and ST321), with the exception of ST7 that showed tolerance to $\mathrm{H}_{2} \mathrm{O}_{2}$ at $10^{\circ} \mathrm{C}$. Isolates of each ST5 and ST9 from different food industry origins showed differences in oxidative stress response. The gene expression of two relevant virulence $(h l y)$ and stress $(c l p C)$ genes was studied in representative isolates in the stressful conditions. hly and $c l p C$ were upregulated during oxidative stress at low temperature. Our results indicate that conditions prevalent in food industries may allow L. monocytogenes to develop survival strategies: these include activating molecular mechanisms based on cross protection that can promote virulence, possibly increasing the risk of virulent strains persisting in food processing plants.
\end{abstract}

Keywords: pathogen; virulence; survival; food industry; oxidizing agents; gene expression

\section{Introduction}

The bacterium Listeria monocytogenes is ubiquitous, and able to survive and grow at a wide range of temperatures, and in alkaline or acid media and high osmolality conditions [1]. Most of these stressful conditions are common in food processing environments (FPE) and inside the human host during infection [2]. L. monocytogenes is exposed to acid and high osmolality within food matrices (e.g. in dairy products after fermentation or in brine tanks and after addition of food preservatives) [3]. Likewise, gastric acid provides a harsh environment [4].

L. monocytogenes is exposed to diverse stresses in FPEs and during infection. Refrigeration to preserve food products both in production facilities and in consumers' fridges imposes low temperatures, and oxidative stress is caused by sanitizer agents, especially disinfectant application and antibiotic 
treatments [5,6]. Disinfectants based on quaternary ammonium compounds are the most common bactericidal agents used in the food industry, and chlorine derivates or peracetic acid are also applied to prevent L. monocytogenes spread within facilities [7]. Hydrogen peroxide $\left(\mathrm{H}_{2} \mathrm{O}_{2}\right)$ is a non-toxic, hydro-soluble and bacteriostatic or bactericidal agent also commonly used as a disinfectant [8]. Oxidizing agents cause several types of damage in cells, affecting the peptidoglycan wall and cell membrane, denaturing proteins and disrupting nucleic acid structure [6,9]. L. monocytogenes can sense stressful conditions through molecular signalling [10] and activates survival strategies to reduce oxidative damage; these strategies include expression of $\operatorname{sig} \mathrm{B}$, cold and heat shock proteins $(\operatorname{csp} \mathrm{ABCD})$, proteases $(\operatorname{cl} \mathrm{C}, c l p \mathrm{P}, g r o \mathrm{EL})$ and genes related to oxidative response notably superoxide dismutase (sod), per $\mathrm{R}$ and catalase (kat) [11-13]. sigB acts on genes related to stress (GRS) and virulence genes such as inlA and LIPI-1 [5]. L. monocytogenes virulence can increase under stress conditions: prfA is regulated by a sigB-depedent promoter, and $c l p C$ expression influences some genes responsible for adherence $[13,14]$. This relation between virulence and the stress response illustrates how L. monocytogenes may protect itself in different stressful conditions, being able to survive in environments with multiple stress factors [15].

The first aim of this study was to analyse the effect of oxidizing agents on the growth of L. monocytogenes at optimal and refrigeration temperatures. The second was to study changes in hly and $c l p C$ expression to investigate the relationship between virulence and the oxidative stress response.

\section{Materials and Methods}

\subsection{Bacterial and Culture Conditions}

Table 1 collects the information of the eleven strains used in this study that were previously isolated and characterized in Manso et al. and Melero et al. $[3,16,17]$. The strains of L. monocytogenes belonged to eight sequence types (ST) (ST1 $(n=1)$, ST5 $(n=2)$, ST6 $(n=1)$, ST7 $(n=1)$, ST9 $(n=3)$, ST87 $(n=1)$, ST199 $(n=1)$ and ST321 $(n=1))$. Moreover, they were isolated from three food processing plants: six strains from a poultry meat factory, four from a dairy plant and one from a seafood company. They were found on non-food contact surfaces $(n=6)$, food contact surfaces $(n=2)$ and food $(n=3)$ samples. They were grown on Chromogenic Listeria Agar ISO (Oxoid, United Kingdom) at $37^{\circ} \mathrm{C}$ for 48 hours. One single colony from each OCLA plates was streaked onto Tryptone Soya Agar (TSA, Oxoid) plates supplemented with $0.6 \%$ yeast extract (YE, Pronadisa, Madrid, Spain) and incubated at $37^{\circ} \mathrm{C}$ for 24 hours. A single colony from each plate was used to inoculate $5 \mathrm{~mL}$ of Brain Heart Infusion broth (BHI broth) (Oxoid) and incubated statically overnight at $37^{\circ} \mathrm{C}$.

\subsection{Oxidative Stress Assay}

L. monocytogenes strains were grown in RPMI broth medium (1× RPMI-1640 Medium, HyClone ${ }^{\mathrm{TM}}$ and $2.05 \mathrm{mM}$ L-Glutamine, GE Healthcare Life Sciences) [18] supplemented with oxidative agents according to Rea et al. [19] but with some modifications. Approximately $10^{9} \mathrm{cfu} / \mathrm{mL}$ of the overnight culture was inoculated to $50 \mathrm{~mL}$ fresh medium (BHI broth) and incubated until mid-exponential phase $\left(\mathrm{OD}_{600} \sim 0.8\right)$ with shaking. After that, the overnight culture was distributed in $10 \mathrm{~mL}$ and centrifuged at $14,600 \times g$ for $5 \mathrm{~min}$ at room temperature. The bacterial pellets were collected, washed with Ringer solution (Oxoid), and centrifuged again as previously. The pellets were then resuspended in $10 \mathrm{~mL}$ of RPMI medium containing $8 \mathrm{mg} / \mathrm{mL}$ ferric citrate (Sigma, San Luis, Misuri, USA) and $13.8 \mathrm{mM}$ cumene hydroperoxide (CHP) (Aldrich) [20], or $100 \mathrm{mM}$ hydrogen peroxide $\left(\mathrm{H}_{2} \mathrm{O}_{2}\right)$ (VWR Chemicals), or with no added agent (controls). These Listeria cultures were incubated at $10^{\circ} \mathrm{C}$ and $37^{\circ} \mathrm{C}$ for 4 hours, and two aliquots were taken after 2, 3 and 4 hours for enumeration and RNA extraction. Serial decimal dilutions were streaked onto TSAYE plates and were incubated at $37^{\circ} \mathrm{C}$ for 24 hours to calculate the susceptibility of $L$. monocytogenes strains against oxidative stress conditions. All the experiments were performed in triplicate. 
Table 1. L. monocytogenes log count reduction after exposure to oxidizing agents $\left(\mathrm{CHP}\right.$ and $\left.\mathrm{H}_{2} \mathrm{O}_{2}\right)$ at $37^{\circ} \mathrm{C}$ and $10{ }^{\circ} \mathrm{C}$.

\begin{tabular}{|c|c|c|c|c|c|c|c|c|c|c|c|c|c|c|c|}
\hline \multirow{3}{*}{ Food Industry } & \multirow{3}{*}{ Sample Type } & \multirow{3}{*}{ Lineage } & \multirow{3}{*}{ Strains } & \multicolumn{4}{|c|}{$\mathrm{CHP}$ at $37^{\circ} \mathrm{C}^{\mathrm{a}}$} & \multicolumn{4}{|c|}{$\mathrm{CHP}$ at $10^{\circ} \mathrm{C}$} & \multicolumn{4}{|c|}{$\mathrm{H}_{2} \mathrm{O}_{2}$ at $10^{\circ} \mathrm{C}^{\mathrm{b}}$} \\
\hline & & & & T1 & $\mathrm{T} 2$ & T3 & Stn.Error & T1 & T2 & T3 & Stn.Err & T1 & T2 & T3 & Stn.Error \\
\hline & & & & Mean & Mean & Mean & & Mean & Mean & Mean & & Mean & Mean & Mean & \\
\hline \multirow{4}{*}{ Cheese making factory } & Cheese crumbs & $I^{d}$ & ST5 ${ }^{f}$ & 5.70 & 8.35 & $9.13 *$ & 0.430 & 0.93 & 1.43 & 1.93 & 0.256 & 1.15 & 1.98 & 1.64 & 0.212 \\
\hline & Floor & $\mathrm{II}^{\mathrm{e}}$ & ST7 & 5.61 & 7.49 & $9.05 *$ & 0.611 & 1.46 & 2.01 & 2.36 & 0.592 & 0.85 & 1.54 & 2.53 & 0.752 \\
\hline & Cheese crumbs & I & ST6 & 4.47 & 7.77 & $8.95 *$ & 0.148 & 1.95 & 1.60 & 1.96 & 0.597 & 1.59 & 3.47 & 4.43 & 0.691 \\
\hline & Cheese crumbs & II & ST9 $\#$ & 6.75 & 8.99 & $9.14 *$ & 0.106 & 0.75 & 1.64 & 2.24 & 0.237 & 1.39 & 3.64 & $9.15^{*}$ & 0.184 \\
\hline \multirow{6}{*}{ Meat processing plant } & Drain & I & ST87 \# & 5.02 & 7.45 & 8.20 & 0.831 & 1.37 & 2.12 & 2.77 & 0.130 & 0.11 & 0.68 & 1.20 & 0.150 \\
\hline & Boxes & I & ST5 $\#$ & 5.17 & 7.57 & 9.00 & 0.251 & 1.19 & 1.67 & 2.35 & 0.098 & -0.04 & 1.85 & 2.92 & 0.627 \\
\hline & Floor & II & ST9 \# & 6.07 & 8.95 & $9.25 *$ & 0.171 & 1.50 & 1.96 & 2.60 & 1.150 & 3.50 & 7.15 & $9.30 *$ & 1.312 \\
\hline & Wall & II & ST9 & 7.23 & $9.23 *$ & $9.23 *$ & 0.301 & 2.09 & 2.46 & 3.18 & 1.061 & 3.79 & $9.12 *$ & $9.12 *$ & 0.668 \\
\hline & Floor & I & ST1 & 4.19 & 6.08 & 7.88 & 0.746 & 1.88 & 1.72 & 1.59 & 1.037 & 0.94 & 2.41 & 4.74 & 0.106 \\
\hline & Drain & II & ST199 & 6.42 & 7.97 & $8.71 *$ & 0.621 & 2.07 & 2.68 & 4.07 & 0.495 & 3.88 & $8.62 *$ & $8.62 *$ & 0.114 \\
\hline Seafood company & Water machine & II & ST321 \# & 7.57 & $8.92 *$ & $8.92 *$ & 0.679 & 1.57 & 3.48 & 4.43 & 0.549 & 0.97 & 3.71 & 7.97 & 0.600 \\
\hline
\end{tabular}

$\left({ }^{*}\right)$ Maximum count reduction; ${ }^{\text {a }}$ Cumene hydroperoxide $(\mathrm{CHP}) ;{ }^{\mathrm{b}}$ Hydrogen peroxide $\left(\mathrm{H}_{2} \mathrm{O}_{2}\right) ;{ }^{\mathrm{c}}$ Standard error (SE); ${ }^{\mathrm{d}}$ Lineage I; ${ }^{\mathrm{e}}$ Lineage II; ${ }^{\mathrm{f}}$ Sequence type (ST). ${ }^{\text {f }}$ Strains chosen to gene expression analyses by RT-PCR. 


\subsection{RNA Extraction and Gene Expression}

Five out of the eleven L. monocytogenes strains (ST87, ST5 and ST9 -from a meat industry-; ST9 from a dairy plant and the ST321 from a seafood company) were chosen to perform RNA extraction using the RNA Pure Link ${ }^{\mathrm{TM}}$ RNA Mini Kit (Invitrogen, Carlsbad, California, USA) following the manufacturer's recommendations (Table 1). RNA samples were reverse transcribed using the ImProm-II ${ }^{\mathrm{TM}}$ Reverse Transcription System (Promega, USA) as described previously [21]. Resulting cDNAs were diluted 1:20 and used as templates for specific real-time PCR assays as previously described [21] in a StepOne Real-Time PCR System (Applied Biosystems, Foster City, California, USA). Expression of $h l y$ (listeriolysin O gene) [22] and clpC (endopeptidase Clp ATP binding chain gene) [23] was studied and $l d h$ (lactate dehydrogenase gene) [21] was used for normalization results following the $2^{-\Delta \Delta C t}$ quantification method.

\subsection{Statistical Analysis}

A multifactor analysis of variance was used to determine the correlation between the response to each temperature and oxidizing agents in all L. monocytogenes strains. Fisher's least significant difference (LSD) procedure was used to determine any significant differences ( $p$ values $<0.05)$ amongst the means between the results for the oxidative stress at $37{ }^{\circ} \mathrm{C}$ and that at $10{ }^{\circ} \mathrm{C}$. (Stat Graphics Centurion XVI software, Stat Graphics Centurion, Madrid, Spain).

\section{Results}

\subsection{Response to Oxidative Stress}

Table 1 shows the results of the oxidative stress in the L. monocytogenes strains tested. L. monocytogenes strains, regardless of their origin or genetic background, were significantly $(p<0.05)$ more tolerant to oxidizing agents $\left(\mathrm{CHP}\right.$ and $\left.\mathrm{H}_{2} \mathrm{O}_{2}\right)$ at $10^{\circ} \mathrm{C}$ than at $37^{\circ} \mathrm{C}$. The stress response was also significantly different $(p<0.05)$ between $\mathrm{CHP}$ and $\mathrm{H}_{2} \mathrm{O}_{2}$, and the mean $\mathrm{H}_{2} \mathrm{O}_{2}$ effect was significantly higher $(p<0.05)$ (Table 1$)$.

The response to oxidative stress differed between strains at the same temperature depending on the food industry origin (Table 1). The oxidative stress response to $\mathrm{CHP}$ at $37^{\circ} \mathrm{C}$ differed between ST5 and ST9 strains depending on the sample types and site of isolation (Table 1) although the differences overall between strains at $37^{\circ} \mathrm{C}$ were not significant $(p=1)$. The ST9 strain isolated from a floor in a meat processing plant was more resistant to $\mathrm{CHP}$ at $37^{\circ} \mathrm{C}$ during the first hour (reduction of $6.07 \mathrm{log}$ units); however, ST9 strains isolated from a wall in the same meat factory and from cheese crumbs showed higher count reductions (6.75 and $7.23 \mathrm{log}$ unit, respectively) (Table 1). Similarly, the count reduction during the first hour for the ST5 strain isolated from the meat processing plant was lower than that for the ST5 strain isolated from the dairy plant (5.17 vs 5.70 log units) and it continued to survive after $3 \mathrm{~h}$ (Table 1). The ST321 strain from the seafood facility and the ST9 strain from the meat factory wall were not detectable after $2 \mathrm{~h}$ of incubation, whereas strains from the meat processing plant, belonging to ST1 (7.88 log unit decline), ST87 (8.20 log unit decline) and ST5 (9 log unit decline), survived for $3 \mathrm{~h}$ (Table 1). Similarly, the stress response to $\mathrm{CHP}$ at $10{ }^{\circ} \mathrm{C}$ was different within ST5 and ST9 strains; the reduction for the isolates from cheese crumbs was lower than those for the isolates from the meat processing plant: 1.93 and $2.24 \log$ unit reduction vs. 2.35 and 2.60 and 3.18 log unit reduction after $3 \mathrm{~h}$ of incubation, respectively (Table 1). The LSD Test indicated that the ST9 strain from the wall sample (meat processing) and the ST199 strain were significantly the most susceptible $(p=0.0129)$ to all the other strains at $10^{\circ} \mathrm{C}$; both were the most susceptible strains at refrigeration temperature. By contrast, ST1 and ST6 strains were the most resistant to CHP at $10{ }^{\circ} \mathrm{C}$ (Table 1).

Similar to our observations for $\mathrm{CHP}$, lower temperature moderated the effect of the oxidative stress; L. monocytogenes strains were more tolerant to $\mathrm{H}_{2} \mathrm{O}_{2}$ at $10{ }^{\circ} \mathrm{C}$ than at $37^{\circ} \mathrm{C}$ regardless the origin or genetic background of the strains. The oxidative stress response in L. monocytogenes to $\mathrm{H}_{2} \mathrm{O}_{2}$ at $37^{\circ} \mathrm{C}$ was higher than to $\mathrm{CHP}$. No colonies were found after just 1 hour of incubation in $\mathrm{H}_{2} \mathrm{O}_{2}$ at $37^{\circ} \mathrm{C}$, 
except for the ST5 strain from the dairy plant and ST87 -7.26 and $6.67 \log$ unit declines, respectively(Data not shown). However, after incubation at $10^{\circ} \mathrm{C}$ for 3 hours, $\mathrm{H}_{2} \mathrm{O}_{2}$ was less toxic than $\mathrm{CHP}$ for the L. monocytogenes strains: count reductions were between 1.20 (ST87) and >9.30 (ST9) log units (Table 1).

\subsection{Gene Expression in Oxidative Stress Conditions}

Figure 1 shows analysis of $h l y$ and $c l p C$ expression under oxidative stress conditions: hly expression was upregulated by oxidative stress (in both $\mathrm{CHP}$ and $\mathrm{H}_{2} \mathrm{O}_{2}$ ), and $c l p \mathrm{C}$ was downregulated. ST9 isolated from meat and ST321 only expressed $h l y$ and $c l p C$ for the first hour in $\mathrm{CHP}$ at $37^{\circ} \mathrm{C}$, and there was a tendency for hly downregulation (Figure 1A).

Strains incubated in CHP showed higher hly expression at $10{ }^{\circ} \mathrm{C}$ than at $37^{\circ} \mathrm{C}$ (Figure 1B). By contrast, $c l p C$ was downregulated in all strains tested during exposure to $\mathrm{CHP}$ regardless of the temperature $\left(37^{\circ} \mathrm{C}\right.$ or $10^{\circ} \mathrm{C}$ ) (Figure $\left.1 \mathrm{~A}, \mathrm{~B}\right)$, with the exception of ST87 that showed $\operatorname{clp} \mathrm{C}$ overexpression after $\mathrm{CHP}$ incubation for 3 hours at $10^{\circ} \mathrm{C}$ (Figure 1B). We have also studied the relation between $h l y$ and $c l p \mathrm{C}$ expression during $\mathrm{CHP}$ exposure at $10{ }^{\circ} \mathrm{C}$ and $37^{\circ} \mathrm{C}$, and it can be observed that $h l y$ expression was significantly higher when exposed to $\mathrm{CHP}$ at $10^{\circ} \mathrm{C}$ the $37^{\circ} \mathrm{C}$, whereas $c l p \mathrm{C}$ expression was lower under oxidative conditions regardless of the temperature (Figure 1C).
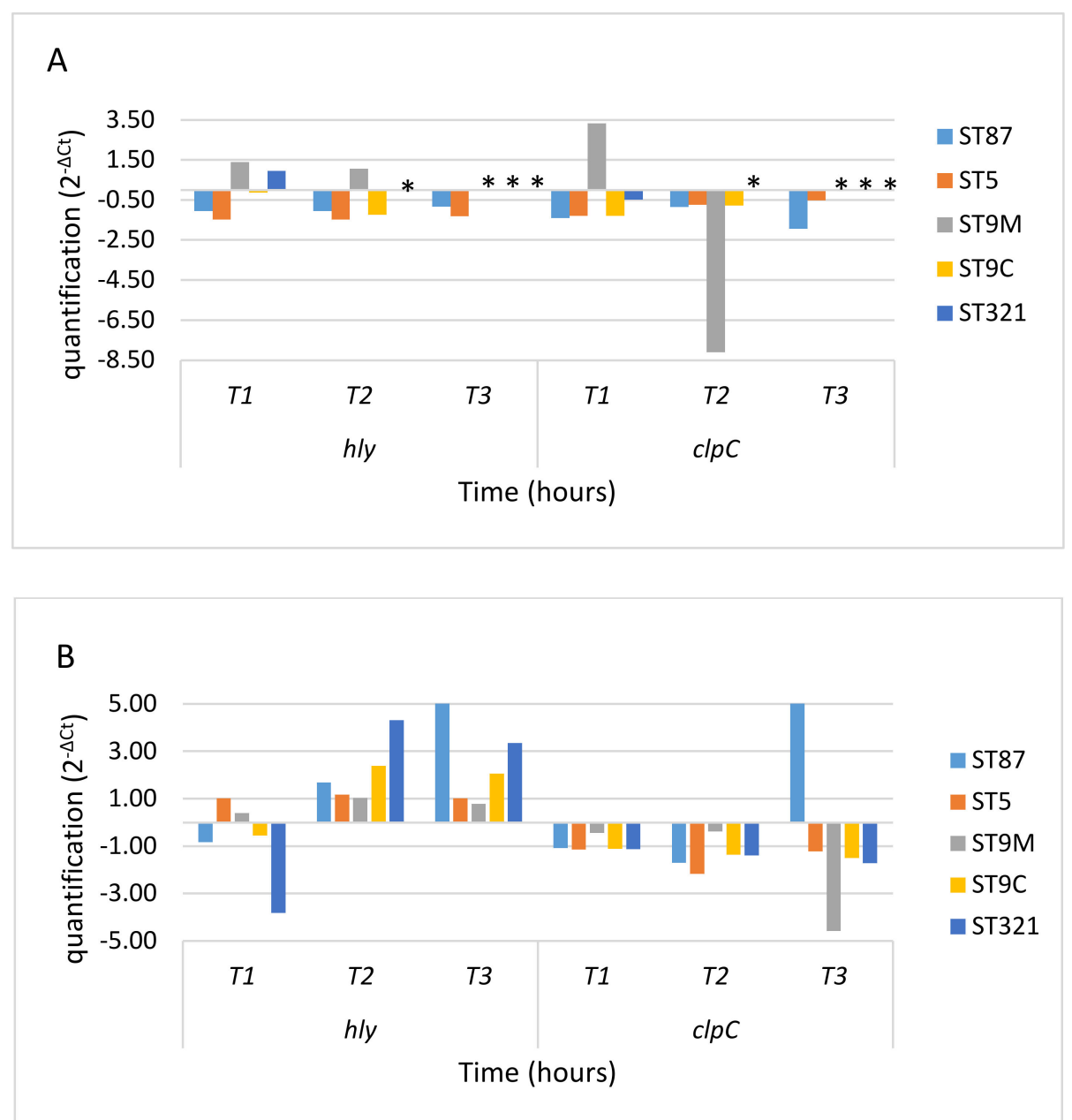

Figure 1. Cont. 

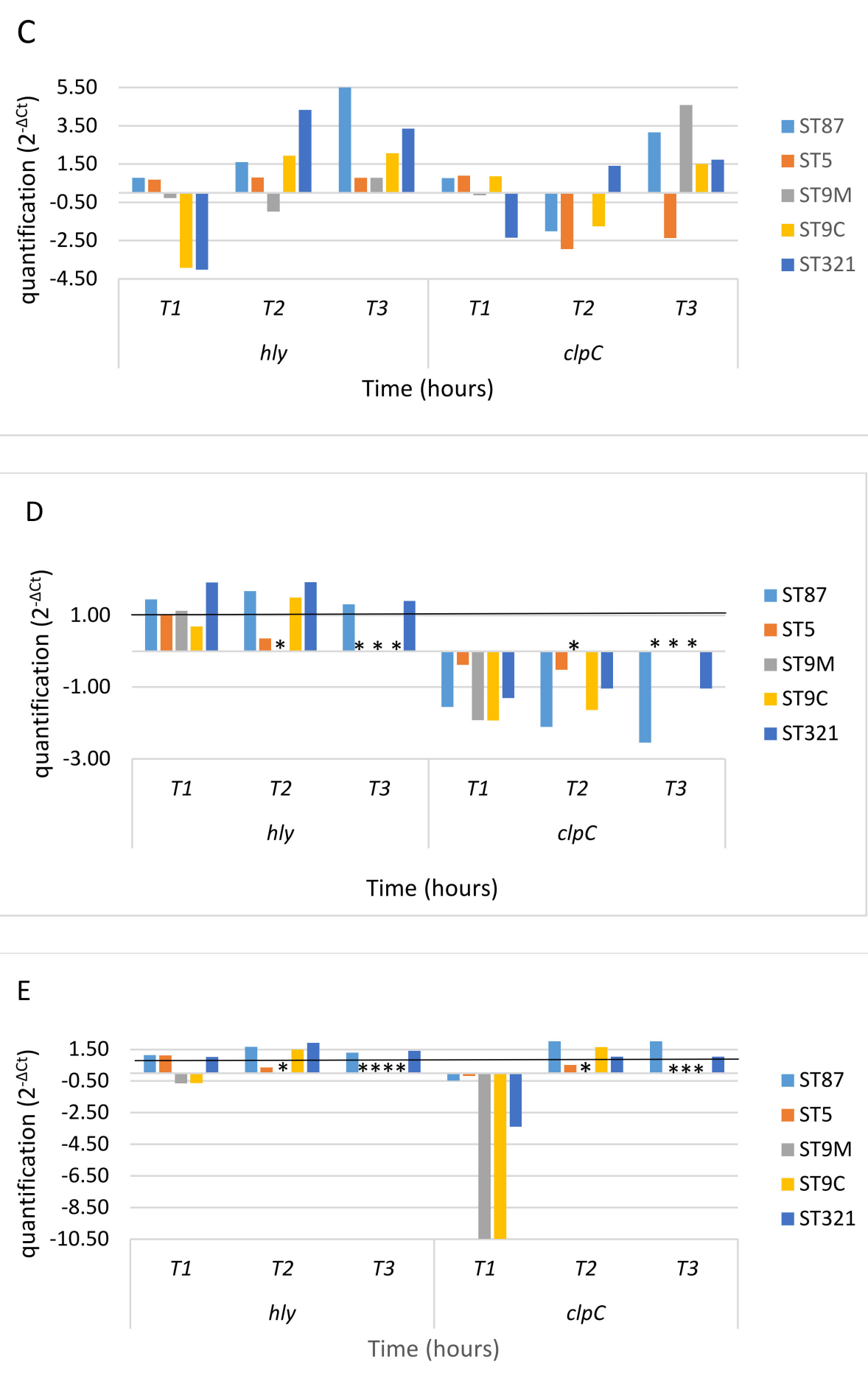

Figure 1. Expression of $h l y$ and $c l p C$ genes during oxidative stress. Transcripts of $h l y$ and $c l p C$ were normalized to those of the $l d h$ gene. Expression of $h l y$ and $c l p C$ after 1, 2 and 3 hours is shown relative to that before the addition of the oxidizing agents. (A) Exposure to $\mathrm{CHP}$ at $37^{\circ} \mathrm{C} ;(\mathbf{B})$ Exposure to $\mathrm{CHP}$ at $10{ }^{\circ} \mathrm{C} ;(\mathbf{C})$ Expression of $h l y$ and $c l p \mathrm{C}$ in $\mathrm{CHP}$ at $10{ }^{\circ} \mathrm{C}$ relative to that at $37^{\circ} \mathrm{C}$; (D) Exposure to $\mathrm{H}_{2} \mathrm{O}_{2}$ at $10{ }^{\circ} \mathrm{C}$; and (E) Expression of $h l y$ and $c l p \mathrm{C}$ in $\mathrm{H}_{2} \mathrm{O}_{2}$ at $10^{\circ} \mathrm{C}$ relative to that at $37^{\circ} \mathrm{C}$. Black line: No differences in gene expression with respect $\mathrm{T}_{0}($ value $=1$ ). * : gene expression results were not studied because cell counts were below the detection limit. T1, T2 and T3: period of time after 1 hour (T1), 2 hours (T2) and 3 hours (T3) of oxidative stress conditions exposure in the L. monocytogenes cultures. 
It was not possible to analyse the gene expression of hly and $c l p C$ in L. monocytogenes strains treated with $\mathrm{H}_{2} \mathrm{O}_{2}$ at $37^{\circ} \mathrm{C}$, because $L$. monocytogenes counts were below the detection limit in less than one hour. Only ST87 and ST321 survived exposure to $\mathrm{H}_{2} \mathrm{O}_{2}$ at $10{ }^{\circ} \mathrm{C}$ : hly was upregulated and $c l p \mathrm{C}$ was downregulated after $3 \mathrm{~h}$ (Figure 1D). The relation between hly and $c l p C$ expression during $\mathrm{H}_{2} \mathrm{O}_{2}$ exposure at $10^{\circ} \mathrm{C}$ and $37^{\circ} \mathrm{C}$ was also studied (Figure 1E): only ST87 and ST321 were able to survive these oxidative conditions, but strains treated with $\mathrm{H}_{2} \mathrm{O}_{2}$ showed hly upregulation, while $\operatorname{clp} \mathrm{C}$ was downregulated although its expression was slightly higher at $10^{\circ} \mathrm{C}$.

\section{Discussion}

L. monocytogenes is a foodborne bacterium commonly found in food processing plants and is able to withstand adverse conditions [1,11]. In food processing environments (FPE), various stressful conditions can influence L. monocytogenes growth and survival, especially refrigeration temperatures, osmotic, acid and oxidative stresses [24,25]. L. monocytogenes is also exposed to stressful conditions in hosts and some are common to FPE stresses: gastric acids provide acid and both invasion of phagolysosomes or macrophages and antibiotic treatments can cause oxidative stress [26,27]. L. monocytogenes is able to increase its tolerance to stressful conditions over time following repeated exposure to sub-lethal doses.

We report here that oxidative stress is temperature and oxidizing compound dependent: the effect was significantly lower at lower temperatures $\left(10^{\circ} \mathrm{C}\right.$ vs $\left.37^{\circ} \mathrm{C}\right)$, and for $\mathrm{CHP}$ than $\mathrm{H}_{2} \mathrm{O}_{2}$. The role of temperature in oxidative stress has also been studied by other authors who reported that lower temperature increased the response to oxidative stress and that there was similar damage to nucleic acids and cell membranes in both stressful conditions [28,29]. In general, detergents and disinfectants $\left(\mathrm{H}_{2} \mathrm{O}_{2}\right.$, paracetic acid and QAC compounds such as $\left.\mathrm{NaOCl}, \mathrm{NH}_{4} \mathrm{OH}_{4}\right)$ used in food industries are applied at refrigeration temperature; this may favour the development in L. monocytogenes of resistance to these sanitizer agents over long period time [24].

Our comparison of $\mathrm{H}_{2} \mathrm{O}_{2}$ and CHP confirms previous reports showing that $\mathrm{H}_{2} \mathrm{O}_{2}$ is a more effective listericidal agent $[27,30]$. The presence of molecular oxygen, growth phase and serovar may all affect the response to oxidative conditions [26,31]. From the point of phenotyping strains results, we found that genotypes belonging to STs of Lineage I (ST5, ST6, ST87, ST1) were more resistant to oxidative stress than those of Lineage II (ST7, ST9, ST199 and ST321), with the exception of ST7 that showed tolerance to $\mathrm{H}_{2} \mathrm{O}_{2}$ at $10{ }^{\circ} \mathrm{C}$, however the differences between strains were not statistically significant. This pattern has been observed previously: L. monocytogenes serovar $1 / 2 \mathrm{a}$ (Lineage II) is more sensitive than $4 \mathrm{~b}$ strains (Lineage I) to $0.6 \% \mathrm{H}_{2} \mathrm{O}_{2}$ [24,32].

The differences between lineages may be due to difference in transcription of genes regulating and encoding oxidative responses. L. monocytogenes expresses molecular mechanisms based on stress regulator genes ( $s i g \mathrm{~B}, c t s \mathrm{R}, h r c \mathrm{~A}, \operatorname{lex} \mathrm{A}$ or $r e c \mathrm{~A}$ ) and response genes (fri, kat, per $\mathrm{R}$ or sod) against oxidative stress [28,32]. Most of the genes involved in stress responses in L. monocytogenes are regulated by $s i g \mathrm{~B}$ factor and they include $c t s \mathrm{R}$, that is the $c l p$ operon repressor during optimal conditions. Clp family proteins (chaperones and proteases) are generally influenced by temperature [33] and stressful conditions. Likewise, $c l p \mathrm{C}$ is also implicated in the responses to oxidative or high osmolality stresses and iron starvation [13,34]. However, $k a t$ is frequently considered the most relevant gene oxidative stress response together with sod, even at low temperature as Azizoglu \& Kathariou (2010) [35] described how kat mutant strains showed smaller colonies size and less tolerance to refrigeration or freeze temperatures. In addition, the response to $\mathrm{H}_{2} \mathrm{O}_{2}$ by kat could be interfered by the enzymatic reaction from food products [36]. Wherefore, the present study was focused on the expression of $c l p C$ as representative gene in response to oxidative stress combined with different temperature incubation. It is well known that L. monocytogenes virulence is found in island LIPI-1, regulated by prf A [37]. Listeriolyin $\mathrm{O}$ is encoded by hly and its expression could be modified during exposure to range of temperature, osmotic and oxidative environmental conditions [38,39]. However, some studies supported the connection between stress conditions with virulence due to the relation among sig $\mathrm{B}$ and $\operatorname{prf} \mathrm{A}$, as prf $\mathrm{A}$ has three significant promotors dependent of sigA and sigB [14]. This inter-genetic 
relation could explain why stressed L. monocytogenes strains could increase their virulence, although the reaction against the stress could be different depending on possible $p r f \mathrm{~A}$ promotor sequence [40].

This study reported that $c l p C$ was overexpressed in some L. monocytogenes strains at $37^{\circ} \mathrm{C}$ in the presence of both of oxidizing agents and its expression was downregulated in $\mathrm{H}_{2} \mathrm{O}_{2}$ at $10{ }^{\circ} \mathrm{C}$; these findings implicate $c l p C$ in the responses to oxidative and heat stresses. Similar results were described by Ochiai et al. [28]. The relationship between stress exposure and virulence in L. monocytogenes has been studied previously. Van der Veen and Abee. [13] reported that $c l p C$ mutant strains $(\Delta c l p C)$ can survive inside of macrophages and other host cells; Chastanet et al. [33] found that $c l p \mathrm{P}$ mutants were unable to grow intracellularly; and the promotors of $\operatorname{prf} \mathrm{A}\left(\mathrm{p} P r f \mathrm{~A}_{1}\right.$ and $\left.\mathrm{p} P r f \mathrm{~A}_{2}\right)$ and $\operatorname{sig} \mathrm{B}(\operatorname{sig} \mathrm{A}$ and sigB) are intrinsically regulated [34].

In conclusion, this study describes for the first time the effect of two different oxidizing agents at two temperatures (optimal growth temperature and the refrigeration temperature in food industries) at the same time on different genotypes of L. monocytogenes. The oxidative effect is temperature dependent, being lower at $10^{\circ} \mathrm{C}$ than $37^{\circ} \mathrm{C}$. The virulence LIPI-1 genes were more strongly expressed when oxidative agents were applied at refrigeration temperatures.

Author Contributions: Conceptualization, D.R.-L., J.R., M.W. and B.M. (Beatriz Melero); methodology, B.M. (Beatriz Manso), B.S.;; formal analysis, D.R.-L., J.R., I.J. and B.M. (Beatriz Melero); writing-original draft preparation, B.M. (Beatriz Manso); writing-review and editing, B.M. (Beatriz Melero) and D.R.-L.; supervision, B.M. (Beatriz Melero) and D.R.-L.; supervision; project administration, I.J.; funding acquisition, D.R.-L., J.R., and M.W. All authors have read and agreed to the published version of the manuscript.

Funding: This research was funded by European Union (EU), grant number 265877 (European 7th Framework Program).

Conflicts of Interest: The authors declare no conflict of interest.

\section{References}

1. Ferreira, V.; Wiedmann, M.; Teixeira, P.; Stasiewicz, M.J. Listeria monocytogenes persistence in food-associated environments: Epidemiology, strain characteristics, and implications for public health. J. Food Prot. 2014, 77, 150-170. [CrossRef] [PubMed]

2. Bergholz, T.M.; Shah, M.K.; Burall, L.S.; Rakic-Martinez, M.; Datta, A.R. Genomic and phenotypic diversity of Listeria monocytogenes clonal complexes associated with human listeriosis. Appl. Microbiol. Biotechnol. 2018, 102, 3475-3485. [CrossRef]

3. Melero, B.; Stessl, B.; Manso, B.; Wagner, M.; Esteban-Carbonero, Ó.J.; Hernández, M.; Rovira, J.; Rodriguez-Lázaro, D. Listeria monocytogenes colonization in a newly established dairy processing facility. Int. J. Food Microbiol. 2019, 289, 64-71. [CrossRef] [PubMed]

4. Braschi, G.; Serrazanetti, D.I.; Siroli, L.; Patrignani, F.; De Angelis, M.; Lanciotti, R. Gene expression responses of Listeria monocytogenes Scott A exposed to sub-lethal concentrations of natural antimicrobials. Int. J. Food Microbiol. 2018, 286, 170-178. [CrossRef] [PubMed]

5. Pereira, S.A.; Alves, Â.; Ferreira, V.; Teixeira, P.C.M. The impact of environmental stresses in the virulence traits of Listeria monocytogenes relevant to food safety. In Listeria Monocytogenes; IntechOpen: London, UK, 2018.

6. Tezel, U.; Pavlostathis, S.G. Quaternary ammonium disinfectants: Microbial adaptation, degradation and ecology. Curr. Opin. Biotechnol. 2015, 33, 296-304. [CrossRef] [PubMed]

7. Soumet, C.; Ragimbeau, C.; Maris, P. Screening of benzalkonium chloride resistance in Listeria monocytogenes strains isolated during cold smoked fish production. Lett. Appl. Microbiol. 2005, 41, 291-296. [CrossRef]

8. Yun, H.S.; Kim, Y.; Oh, S.; Jeon, W.M.; Frank, J.F.; Kim, S.H. Susceptibility of Listeria monocytogenes biofilms and planktonic cultures to hydrogen peroxide in food processing environments. Biosci. Biotechnol. Biochem. 2012, 76, 2008-2013. [CrossRef]

9. Harter, E.; Wagner, E.M.; Zaiser, A.; Halecker, S.; Wagner, M.; Rychli, K. The novel stress survival islet 2 (SSI-2), predominantly present in Listeria monocytogenes strains of ST121, is involved in alkaline and oxidative stress response. Appl. Environ. Microbiol. 2017, 83, e00827-17. [CrossRef] 
10. Freitag, N.E.; Port, G.C.; Miner, M.D. Listeria monocytogenes from saprophyte to intracellular pathogen. Nat. Rev. Microbiol. 2009, 7, 623. [CrossRef]

11. Markkula, A.; Lindström, M.; Johansson, P.; Björkroth, J.; Korkeala, H. Role of four putative DEAD-box RNA helicase genes in growth of Listeria monocytogenes EGD-e under heat, $\mathrm{pH}$, osmotic, ethanol, and oxidative stresses. Appl. Environ. Microbiol. 2012, 78, 6875-6882. [CrossRef]

12. Suo, Y.; Huang, Y.; Liu, Y.; Shi, C.; Shi, X. The expression of superoxide dismutase (SOD) and a putative ABC transporter permease is inversely correlated during biofilm formation in Listeria monocytogenes $4 \mathrm{~b}$ G. PLoS ONE 2012, 7, e48467. [CrossRef] [PubMed]

13. Van der Veen, S.; Abee, T. Contribution of Listeria monocytogenes RecA to acid and bile survival and invasion of human intestinal Caco-2 cells. Int. J. Med. Microbiol. 2011, 301, 334-340. [CrossRef] [PubMed]

14. Kuhn, M.; Goebel, W. Molecular virulence determinants of Listeria monocytogenes. Food Sci. Technol. 2017, 161, 111.

15. Komora, N.; Bruschi, C.; Magalhães, R.; Ferreira, V.; Teixeira, P. Survival of Listeria monocytogenes with different antibiotic resistance patterns to food-associated stresses. Int. J. Food Microbiol. 2017, 245, 79-87. [CrossRef] [PubMed]

16. Manso, B.; Melero, B.; Stessl, B.; Fernández-Natal, I.; Jaime, I.; Hernández, M.; Wagner, M.; Rovira, J.; Rodríguez-Lázaro, D. Characterization of virulence and persistence abilities of Listeria monocytogenes strains isolated from food processing premises. J. Food Prot. 2019, 82, 1922-1930. [CrossRef]

17. Melero, B.; Manso, B.; Stessl, B.; Hernandez, M.; Wagner, M.; Rovira, J.; Rodriguez-Lazaro, D. Distribution and persistence of Listeria monocytogenes in a heavily contaminated poultry processing facility. J. Food Prot. 2019, 82, 1524-1531. [CrossRef]

18. Ciolacu, L.; Nicolau, A.I.; Wagner, M.; Rychli, K. Listeria monocytogenes isolated from food samples from a Romanian black market show distinct virulence profiles. Int. J. Food Microbiol. 2015, 209, 44-51. [CrossRef]

19. Rea, R.; Hill, C.; Gahan, C.G. Listeria monocytogenes PerR mutants display a small-colony phenotype, increased sensitivity to hydrogen peroxide, and significantly reduced murine virulence. Appl. Environ. Microbiol. 2005, 71, 8314-8322. [CrossRef]

20. Huang, Y.; Suo, Y.; Shi, C.; Szlavik, J.; Shi, X.M.; Knøchel, S. Mutations in gltB and gltC reduce oxidative stress tolerance and biofilm formation in Listeria monocytogenes 4b G. Int. J. Food Microbiol. 2013, 163, 223-230. [CrossRef]

21. Bielecka, M.K. Exploration into the Virulence Mechanisms of Listeria. Ph.D. Thesis, University of Edinburgh, Edinburgh, UK, 2011.

22. Rodríguez-Lázaro, D.; Pla, M.; Scortti, M.; Mozó, H.J.; Vázquez-Boland, J.A. A novel real-Time PCR for Listeria monocytogenes that monitors analytical performance via an internal amplification control. Appl. Environ. Microbiol. 2015, 71, 9008-9012. [CrossRef]

23. Kim, H.; Marquis, H.; Boor, K.J. Sigma B contributes to Listeria monocytogenes invasion by controlling expression of inlA and inlB. Microbiology 2015, 151, 3215-3230. [CrossRef] [PubMed]

24. Abeysundara, P.D.A.; Nannapaneni, R.; Soni, K.A.; Sharma, C.S.; Mahmoud, B. Induction and stability of oxidative stress adaptation in Listeria monocytogenes EGD (Bug600) and F1057 in sublethal concentrations of $\mathrm{H}_{2} \mathrm{O}_{2}$ and $\mathrm{NaOH}$. Int. J. Food Microbiol. 2016, 238, 288-294. [CrossRef] [PubMed]

25. Al-Nabulsi, A.A.; Osaili, T.M.; Shaker, R.R.; Olaimat, A.N.; Jaradat, Z.W.; Elabedeen, N.A.Z.; Holley, R.A. Effects of osmotic pressure, acid, or cold stresses on antibiotic susceptibility of Listeria monocytogenes. Food Microbiol. 2015, 46, 154-160. [CrossRef] [PubMed]

26. Boura, M.; Keating, C.; Royet, K.; Paudyal, R.; O'Donoghue, B.; O’Byrne, C.P.; Karatzas, K.A. Loss of sigB in Listeria monocytogenes strains EGD-e and $10403 \mathrm{~S}$ confers hyperresistance to hydrogen peroxide in stationary phase under aerobic conditions. Appl. Environ. Microbiol. 2016, 82, 4584-4591. [CrossRef]

27. Dons, L.E.; Mosa, A.; Rottenberg, M.E.; Rosenkrantz, J.T.; Kristensson, K.; Olsen, J.E. Role of the Listeria monocytogenes 2-Cys peroxiredoxin homologue in protection against oxidative and nitrosative stress and in virulence. Pathog. Dis. 2014, 70, 70-74. [CrossRef] [PubMed]

28. Ochiai, Y.; Yamada, F.; Yoshikawa, Y.; Mochizuki, M.; Takano, T.; Hondo, R.; Ueda, F. Sequential transition of the injury phenotype, temperature-dependent survival and transcriptional response in Listeria monocytogenes following lethal $\mathrm{H}_{2} \mathrm{O}_{2}$ exposure. Int. J. Food Microbiol. 2017, 259, 52-58. [CrossRef]

29. Tasara, T.; Stephan, R. Cold stress tolerance of Listeria monocytogenes: A review of molecular adaptive mechanisms and food safety implications. J. Food Prot. 2016, 69, 1473-1484. [CrossRef] 
30. Ferreira, A.; O'Byrne, C.P.; Boor, K.J. Role of sigma B in heat, ethanol, acid, and oxidative stress resistance and during carbon starvation in Listeria monocytogenes. Appl. Environ. Microbiol. 2001, 67, 4454-4457. [CrossRef]

31. Ivy, R.A.; Wiedmann, M.; Boor, K.J. Listeria monocytogenes grown at $7^{\circ} \mathrm{C}$ shows reduced acid survival and an altered transcriptional response to acid shock compared to L. monocytogenes grown at $37^{\circ} \mathrm{C}$. Appl. Environ. Microbiol. 2012, 8, 3824-3836. [CrossRef]

32. Huang, Y.; Morvay, A.A.; Shi, X.; Suo, Y.; Shi, C.; Knøchel, S. Comparison of oxidative stress response and biofilm formation of Listeria monocytogenes serotypes $4 \mathrm{~b}$ and 1/2a. Food Control 2018, 85, 416-422. [CrossRef]

33. Chastanet, A.; Derre, I.; Nair, S.; Msadek, T. $\operatorname{clpB}$, a novel member of the Listeria monocytogenes CtsR regulon, is involved in virulence but not in general stress tolerance. J. Bacteriol. 2004, 186, 1165-1174. [CrossRef] [PubMed]

34. Chaturongakul, S.; Raengpradub, S.; Wiedmann, M.; Boor, K.J. Modulation of stress and virulence in Listeria monocytogenes. Trends Microbiol. 2018, 16, 388-396. [CrossRef] [PubMed]

35. Azizoglu, R.O.; Kathariou, S. Temperature-dependent requirement for catalase in aerobic growth of Listeria monocytogenes F2365. Appl Environ Microbiol. 2010, 76, 6998-7003. [CrossRef] [PubMed]

36. Møretrø, T.; Fanebust, H.; Fagerlund, A.; Langsrud, S. Whole room disinfection with hydrogen peroxide mist to control Listeria monocytogenes in food industry related environments. Int. J. Food Microbiol. 2019, 292, 118-125. [CrossRef] [PubMed]

37. Vázquez-Boland, J.A.; Kuhn, M.; Berche, P.; Chakraborty, T.; Domínguez-Bernal, G.; Goebel, W.; González-Zorn, B.; Wehland, J.; Kreft, J. Listeria pathogenesis and molecular virulence determinants. Clin. Microbiol. Rev. 2001, 14, 584-640. [CrossRef] [PubMed]

38. Eshwar, A.K.; Guldimann, C.; Oevermann, A.; Tasara, T. Cold-shock domain family proteins (Csps) are involved in regulation of virulence, cellular aggregation, and flagella based motility in Listeria monocytogenes. Front. Cell Infect. Microbiol. 2017, 7, 457. [CrossRef]

39. Lee, T.; Jun, S.H.; Choi, C.W.; Kim, S.I.; Lee, J.C.; Shin, J.H. Salt stress affects global protein expression profiles of extracellular membrane- derived vesicles of Listeria monocytogenes. Microb. Pathog. 2017, 115, 272-279. [CrossRef]

40. Nadon, C.A.; Bowen, B.M.; Wiedmann, M.; Boor, K.J. Sigma B contributes to PrfA mediated virulence in Listeria monocytogenes. Infect. Immun. 2002, 70, 3948-3952. [CrossRef]

(C) 2020 by the authors. Licensee MDPI, Basel, Switzerland. This article is an open access article distributed under the terms and conditions of the Creative Commons Attribution (CC BY) license (http://creativecommons.org/licenses/by/4.0/). 